\title{
ESTIMATION OF RURAL HOUSEHOLDS' DEMAND FOR SELECTED STAPLE FOODS IN ENUGU STATE
}

\author{
${ }^{*}$ Ben-Chendo, G.N. ${ }^{1}$, Nwosu, F.O. ${ }^{1}$, Nwaiwu, I.U.O. ${ }^{1}$ and Igwe S.M ${ }^{2}$ \\ ${ }^{I}$ Department of Agricultural Economics, Federal University of Technology Owerri, Imo State \\ ${ }^{2}$ Department of Agricultural Economics, University of Ibadan \\ *Correspondent email: gbenchendo@gmail.com
}

\begin{abstract}
Estimation of household food demand patterns and elasticity is often conceived as an important prerequisite for designing, predicting and analysing agricultural policy impacts. Based on this fact, this study sets out to estimate the food demand of rural households in the study area with a view to identifying its determinants and responsiveness to price and household food expenditure. The study employed a multi-stage sampling technique in the selection 254 rural households in Enugu state and the primary data collected were analysed using Descriptive statistics and Quadratic Almost Ideal Demand System (QUAIDS) model. The result of the descriptive statistics showed that the mean age, household size, and years of education of the sampled rural

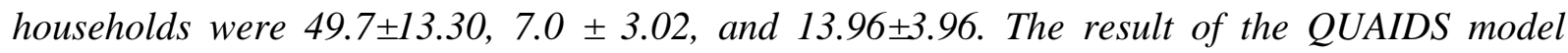
revealed that all the expenditure elasticity for the selected staple food items were positive and hence, regarded as normal goods and In terms of magnitude, all the staple food items except rice and yam have expenditure elasticity less than one and are therefore, regarded as necessities. Own price elasticity were all negative as expected in both uncompensated and compensated price elasticity estimates. The Marshallian cross price elasticity estimates also revealed that almost all the selected staple food items have positive cross-price elasticity values indicating that they are net substitutes while the Hicksian/compensated cross price elasticity revealed that majority of the selected staple food items have negative cross-price elasticity values indicating that they are complements. However, the study further revealed that price, total food expenditure, sex, age, marital status, years of education, household size and household head income were the key determinants of the rural household demand for the selected staple food items in the study area. Based on the foregoing, the result of this study should inform the design of food security related policies aimed at improving the nutritional status of the poor and vulnerable households in the country.
\end{abstract}

Keywords: QUAIDS, Food Demand, Elasticity, Households https://dx.doi.org/10.4314/jafs.v16i1.8 


\section{INTRODUCTION}

One of the most developed economies in Africa is Nigeria with the agricultural sector contributing about $28.65 \%$ to the total annual GDP (NBS, 2016). The economic relevance of the agricultural sector is seen as a vital development tool for achieving the food self-sufficiency goal of the nation (FMARD, 2013). However, despite the significant contribution of this food subsector in the economy, the problem of food insecurity, malnutrition and poverty could be attributed to the poor performance of the agricultural sector, which in turn creates food availability and accessibility problems at the household and national levels. US\$1.25 per day and Nigeria was also ranked $91^{\text {st }}$ out of a total of 104 countries on the 2015 Global Hunger Index and $153^{\text {rd }}$ out of a total of 187 countries on the 2012 UNDP Human Development Index.

The poor performance of this sector has resulted inability of food production to meet up with the high demand high population growth (Ojo, 2003). Three strongly interrelated factors namely: population growth, changes in consumption patterns, lifestyles and urbanization determine demand for food (Pieters, et al., 2013). However, unlike the other three factors, food consumption patterns are often side-lined in food security research and policy related areas (Jones et al., 2013; and Rizov et al., 2015). According to Asogwa and Umeh (2012) the per capita growth and production of major food items in the country on a national level, has not been able to sufficiently satisfy the demand of an increasing population thereby resulting in a wide gap between the national supply and demand for food. In fact, several reports have been published to elucidate a consistent increase in the production of staple food in the country especially between 1999 and 2005, but there is still an observable gap between food demand and food supply (Sanusi et al, 2006).On the other hand, one of the critical issues facing any economic development programme of a country is creating a balance between the demand and supply of food . It is based on this established fact, that the Nigerian government spend huge amount of money on massive importation of food items to compliment domestic food production in lieu of bridging the high demand-supply gap in food sector (Adepujo and Adejare, 2013).

Generally, staples are the main dietary sources of calories and proteins and constitute important sources of micro-nutrients in the diets of several households (Gegios et al., 2010; and Musa et al., 2012). Available statistics has also shown that staples account for about 55 percent of the food budget in Nigeria (NBS, 2012) with majority of the poor households subjecting more than 60 percent of their food expenditure to staples (Ashagidigbi et al., 2012; and Ogunniyi et al., 2012). However, the forgoing underscores the fact that adequate knowledge of the demand structure and consumer behaviour is vital for a wide range of development policy questions like improvement in nutritional status, food subsidy, sectorial and macroeconomic policy analysis, etc., (Mittal, 2006). It has been observed by Thanga (2013) that various demand models give different results for food demand and price elasticity. Moreover, Asagunla and Oyeyemi (2018) Journal of the Faculty of Agriculture and Veterinary Medicine, Imo State University Owerri website: www ajol.info 
Journal of Agriculture and Food Sciences Ben-Chendo, G.N., Nwosu, F.O., Nwaiwu, I.U.O. and Igwe S.M Volume 16 Number 1, April 2018 pp.91-106.

opined that empirical model of demand system is needed in order to apply the demand theory in the real world situation and that several approaches (locally or internationally) such as Linear Expenditure System (LES), Rotterdam Model, Almost Ideal Demand System (AIDS), Linear Approximation Almost Ideal Demand (LA-AIDS) and the Quadratic Almost Ideal Demand System (QUAIDS) have been employed in quantifying the role of household composition in determining household expenditure and demand pattern.

The thrust of this paper is premised on the theory of consumer behaviour and on the need to complement macro-data analysis with micro-data analysis on household demand for staple food. A number studies such as (Akinyele (2009); Obayelu et al (2009); Ashagidigbi (2012); Akerele et al., (2013); Oni and Fashogbon (2013); and Oluwa (2016)), have examined households food demand at Macro-level and Micro-levels in Nigeria but none of them have tried to limit the scope of their study to staple foods in lieu of deriving the nutritional implications of the demand for the food item and the effect or otherwise of unit changes in prices and income of the households. However, this study tends to deviate from others by empirically estimating the household demand for food staple at Micro-level. Furthermore, from the methodological perspective, several studies (Agboola (2003); Akinleye (2009); Ogunnuyi (2011); Adetunji and Rauf (2012) ) had used Almost Ideal Demand and Linear Approximation of the AIDS model to analyse the demand for food with few exploring the Quadratic Almost Ideal Demand System (QUAIDS). Obayelu et al, (2009) and Olorunfemi (2013), used QUAIDS to analyse households' demand for different food groups. This study stems to differentiate itself from theirs, by using a non-linear price and expenditure at a micro level. Additionally, there are some advantages to using QUAIDS. First, LA/AIDS using a linear price index leads to inaccurate price and expenditure elasticity (Alston et al., 1994). Second, AIDS assumes that Engel's curve is linear, but the advantage of QUAIDS model is that it allows a non-liner relationship in the estimation of the Engel curve (Banks et al., 1997).

Several empirical works have been done on estimation of food demand in both developed and developing countries in lieu of knowing whether a significant difference exist in the findings of their study. For instance, Lind and Frandsen (2000) studied food demand behaviour in India using annual time series data covering a period of 30years (1967-1997). They also employed AIDS model and vector error correction approach for the estimation of a dynamic consumer food demand system and their findings revealed that the system fulfilled the theoretical properties of a demand system with price and income elasticity having signs and magnitudes which are in congruent with other studies on demand elasticity. The recursive analysis also revealed that the dynamic system has constant parameters. Karagiannis et al (2000) also applied error correction almost ideal demand system for meat in Greece using annual time series data for the period 1958-1993 and found that all meat items substitutes each other except chicken and mutton-lamb, and pork and chicken. Another study by Chernet al (2002) on food consumption behaviour of 
Journal of Agriculture and Food Sciences $\quad$ Ben-Chendo, G.N., Nwosu, F.O., Nwaiwu, I.U.O. and Igwe S.M Volume 16 Number 1, April 2018 pp. $91-106$.

Japanese households employed linear almost ideal demand system (LA/AIDS) and non-linear almost ideal demand system (AIDS) and found that the expenditure elasticity of rice was positive and close to one, indicating that rice is a normal good. They also found out that Marshallian/uncompensated and Hicksian/compensated own-price elasticity for rice is highly elastic. Moreover, Pomboza and Mbaga (2007) examined food demand elasticity in Canada using Food expenditure survey-2001 data set and modified AIDS model developed by Huang and Lin (2000). They found that own price elasticity were negative, while expenditure elasticity were positive and less than one. A related study by Quang (2008) on food demand in Vietnam, estimated income and price elasticity for three different components of food categories using a linear approximation of almost ideal demand system (AIDS) and extended AIDS model, found out that rice food and meat/fish food were normal goods while non-rice food was luxury.

Sheng et al (2008) estimated a complete demand system of food in Malaysia using linear approximate almost ideal demand system (LA/AIDS) with incorporation of Stone price index and Laspeyres price index. Their findings revealed that the application of Laspeyres price index produced more plausible estimate of expenditure and own-price elasticity in Malaysia and consumers are seeking high protein value food, as well as functionally healthy foods. Nzuma and Sarker (2010) using annual time series data for the period 1963 to 2005 and AIDS model with corrected Stone price index, studied the demand system for major cereals in Kenya. They found that all own-price elasticity were negative and significant while expenditure elasticity of all cereals (rice, wheat, maize and sorghum) were positive and inelastic in both short-run and longrun. Ashagidigbi, et al (2012) using cross sectional data obtained from the Nigerian Living Standard Survey (NLSS) of 2004 by National Bureau of Statistics and quadratic almost ideal demand system (QUAIDS) models examined the determinants of households' food demand in Nigeria. They found that Staple are mostly consumed food group with highest expenditure of $\$ 10,599.6$, while fruits is least consumed with lowest expenditure of $\$ 374$ and that expenditure elasticity of all the food groups, with the exception of fats and fruits are less than unity. Based on the foregoing, Oni and Fashogbon (2013) studied the food demand for 121 rural households in Ondo State. Based on the cross-sectional data collected through the use of 3-stage random sampling technique, they found that grains and starch basket had the largest share (49\%) of household total food expenditure with price, household size, total food expenditure, and expenditure on food away-from-home deemed the key determinants of food demand among rural households. Their findings further revealed that own price elasticity were all negative as expected in both uncompensated and compensated price elasticity estimates while the Hicksian cross-price elasticity showed that all food groups were net substitutes. Another study by Thanga (2013) also x-rayed the food consumption patterns from un-tabulated NSS data for Mizoram State, India and the study found that all food items have negative own price elasticity supporting the proposition of the traditional 'law of demand. However, Widarjono and Rucbha (2016) also analysed the food demand in urban areas of Indonesia using data from the 2011 National Social 
Journal of Agriculture and Food Sciences Ben-Chendo, G.N., Nwosu, F.O., Nwaiwu, I.U.O. and Igwe S.M Volume 16 Number 1, April 2018 pp. $91-106$.

and Economic Survey of Households (SUSENAS) in Indonesia. They found that price and income elasticity become less elastic from poor households to rich households and that demand by urban households in Java is more responsive to price but less responsive to income than urban households outside of Java. Finally, Asagunla and Oyeyemi (2018) studied household expenditure in the rural areas of Ondo state using Multi-stage sampling technique in the selection of 519 households for the study. They found that all expenditure elasticity were positive, indicating that food and non-food items are normal goods. They also discovered that Beans $(0.22)$ and Gari $(0.82)$ are necessities with their elasticity less than one while others are luxury goods since their elasticity are greater than one.

The specific objectives are to examine the determinants of households' food demand in the study area and estimate the demand elasticity of the selected staple foods in the study area.

\section{METHODOLOGY}

The study was conducted in Enugu State located in the south-eastern region of Nigeria, an irregular trapezoid territory between Latitudes $5^{0} 55^{1}$ and $7^{0} 10^{1}$ North and Longitudes $6^{0} 50^{1}$ and $7^{0} 55^{1}$ East. The state shares borders with Abia State and Imo State to the south, Ebonyi State to the east, Benue State to the northeast, Kogi State to the northwest and Anambra State to the west. The State occupies an area of about $7161 \mathrm{~km}^{2}$ and has a population of $3,267,837$ and with average annual growth rate of 3.0\% according to (NPC, 2006). Moreover, Enugu State is made up of seventeen local government areas which is divided into three agricultural zones namely: Awgu zone, as Awgu, Aninri, Enugu South, Nkanu East, Nkanu West and Oji-River; Enugu zone, which are made up of Enugu East, Enugu North, Ezeagu, Igboetitiand Udi; but Nsukka zone are Igboeze North, Igboeze South, Isiuzo, Nsukka, Udenu and Uzo-Uwani. Ecologically, the state has a mean annual rainfall of $1730 \mathrm{~mm}$ and mean annual temperature of $26.3^{\circ} \mathrm{C}$. The soils vary locally but may be grouped into three main types: the red clayey ferralitic soils of the cross River Basin, the red-yellow ferralitic soils of the plateau and the sandy flood-plains of the Anambra basin at the western limits. Economically, the state is predominantly rural and agrarian, with a substantial proportion of its working population engaged in farming and the prevalent crops and economic trees grown in the study area includes cassava, yam, maize, rice, melon, groundnut, pepper, oil palm, cashew, cocoa, oranges, kola nuts, and pears.

The study adopted a multi-stage sampling technique in the selection of representative rural households for the study. The first stage involves random selection of one local government from each of the three (3) senatorial districts in Enugu state: namely; Isi-uzo, Orji River and Igbo-etiti local government from Enugu east, Enugu west and Enugu north senatorial districts respectively. The second stage involves random selection of three communities from the selected local governments out of the list of communities (that was compiled by Enugu State Agricultural Development Programme). In this wise, three villages were selected from Isi-uzo (Iken-nkwo, 
Journal of Agriculture and Food Sciences Ben-Chendo, G.N., Nwosu, F.O., Nwaiwu, I.U.O. and Igwe S.M Volume 16 Number 1, April 2018 pp. $91-106$.

Isienu, and Abor), Orji-river (Ugwunzu, Amankwo, and Achiagu) and Igbo-etiti local government areas (Umuofiagu, Ochima and Diogbe). The final stage involves random selection of 30 households per village to make a total of 270 representative rural households. Out of the 270 copies of questionnaires that were submitted, 16 were incorrectly filled and returned. However, 254 were used in the final analysis.

The objectives of the study were analysed using descriptive statistics such as mean, frequency and percentages and inferential statistics such as QUAIDS model. The descriptive statistics was used to describe the socioeconomic and other relevant variables considered in this study while QUAIDS model as used by Poi (2002) was used in determining the factors affecting food demand as well as estimating of elasticity of the staple food.

The QUAID model developed by banks et al (1996 and 1997) is derived from indirect utility function as thus:

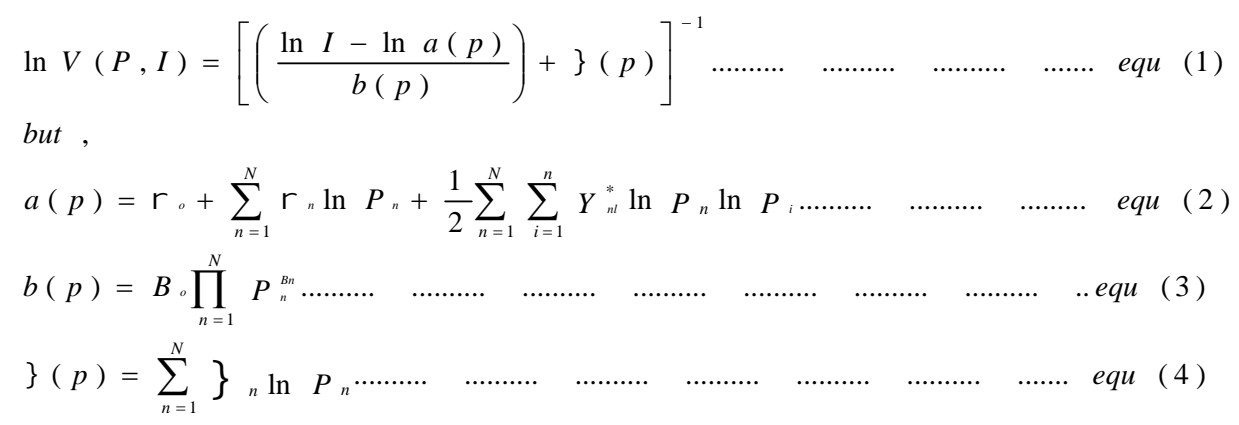

Where, $m$ indicates household income, and $\mathrm{a}(\mathrm{p}), b(p)$ and $\lambda(p)$ are functions of the vector of prices $p$. To ensure the homogeneity property of the indirect utility function, it is required that $a(p)$ is homogenous of degree one in $\mathrm{p}$, and $b(p)$ and $\lambda(p)$ homogenous of degree zero in $p$.

However, by applying Roy's identity to the indirect utility function, the budget shares in the QUAIDS model is explicitly expressed as thus:

$W_{i}=\alpha_{i}+\sum_{j}^{n} Y_{i j} \ln P_{j}+B_{i} \ln \left[\frac{m}{a(p)}\right]+\lambda_{i}\left\{\ln \left[\frac{m}{a(p)}\right]\right\}^{2}+\sum_{j=1}^{l} \delta_{i i} Z_{s}+\varepsilon_{i} \ldots \ldots \ldots \ldots \ldots \ldots$ equ (5)

But, recall that according to Poi (2012), the household expenditure share for good $\mathrm{i}$ is estimated as thus:

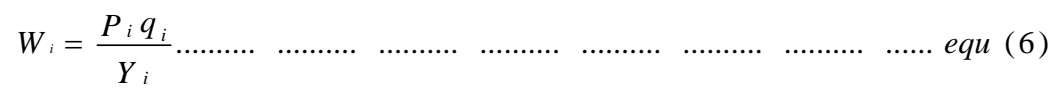

Where, Pi is the price paid for good i, qi is the quantity of good i purchased or consumed and $y$ is the total expenditure on all the goods in the demand system.

With this definition of $\mathrm{Y}, \sum_{i=1}^{k} W_{i}=1$

Journal of the Faculty of Agriculture and Veterinary Medicine, Imo State University Owerri website: www ajol.info 
Journal of Agriculture and Food Sciences $\quad$ Ben-Chendo, G.N., Nwosu, F.O., Nwaiwu, I.U.O. and Igwe S.M Volume 16 Number 1, April 2018 pp. $91-106$.

Where;

$K=$ total number of goods in the system.

$W_{i}=$ household's expenditure share of ith food item, for $\mathrm{i}=1,2,3,4$ and 5

$W_{l}=$ expenditure share for rice

$W_{2}=$ expenditure share for maize

$W_{3}=$ expenditure share for yam

$W_{4}=$ expenditure share for cassava

$W_{5}=$ expenditure share for sweet potatoes

$P_{i}=$ price of ith food item $(\mathbb{N} / \mathrm{kg})$, for $\mathrm{i}=1,2,3,4$ and 5

$P_{1}=$ price of rice $(\mathrm{N} / \mathrm{kg})$

$P_{2}=$ price of maize $(\mathrm{N} / \mathrm{kg})$

$P_{3}=$ price of yam $(\mathrm{N} / \mathrm{kg})$

$P_{4}=$ price of cassava $(\mathrm{N} / \mathrm{kg})$

$P_{5}=$ price of sweet potato $(\mathbb{A} / \mathrm{kg})$

$M=$ household's total expenditure on all food in the demand system ((N/month)

$Z_{i}=$ socioeconomic variables

$Z_{l}=$ age of the household head (years)

$Z_{2}=$ sex of the household head (male $=1$, female $\left.=0\right)$

$Z_{3}=$ marital Status (married $=1$, otherwise $=0$ )

$Z_{4}=$ years of education (years)

$Z_{5}=$ Income of the household head

$e_{i}=$ error term

On the other hand, by taking first derivative of the Equation (5) with respect to expenditure and prices, we have the following:

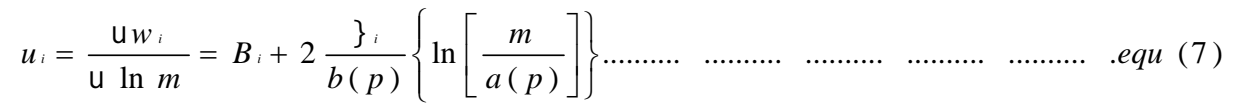

$u_{i j}=\frac{\delta w_{i}}{\delta \ln P_{j}}=Y_{i j}-u_{i}\left(\alpha_{j}+\sum_{k} Y_{j k} \ln P_{k}\right)-\frac{\lambda i B j}{b(p)}\left\{\ln \left[\frac{m}{a(p)}\right]\right\}^{2} \ldots \ldots \ldots \ldots \ldots . . . . . e q u(8)$

From equation (7) and (8), we obtain the expenditure elasticity $\left(e_{i}\right)$, uncompensated price elasticity $\left(e_{i j}^{u}\right)$, and Hicksian or compensated price elasticity $\left(e_{i j}^{c}\right)$ as thus:

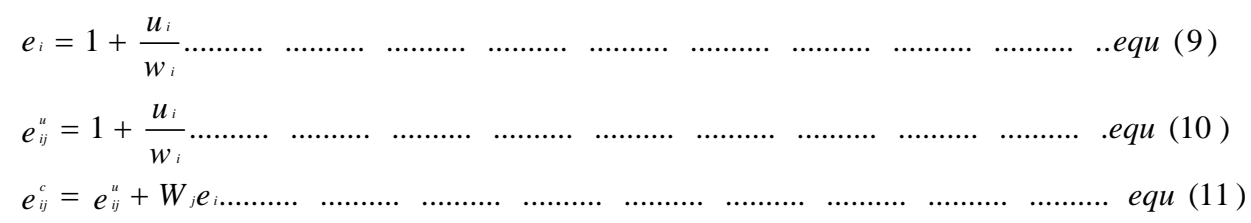

\section{RESULTS AND DISCUSSION}

As shown in Table 1, majority $(60.24 \%)$ of the rural households sampled were headed by males with $39.76 \%$ been headed by the female counterparts. Most of rural household heads were within

Journal of the Faculty of Agriculture and Veterinary Medicine, Imo State University Owerri website: www ajol.info 
Journal of Agriculture and Food Sciences $\quad$ Ben-Chendo, G.N., Nwosu, F.O., Nwaiwu, I.U.O. and Igwe S.M Volume 16 Number 1, April 2018 pp. $91-106$.

the age range of 41-60 years with only a few above 60 years of age. The mean age of the rural household heads stood at 49.7 years, implying that majority of the respondents were in their economically active working age and this collaborates with the findings of Ashagidigbi et $a l,(2012)$ and Adepoju and Adejare (2013). More so, about $77.95 \%$ of the sampled rural household heads were married while others $(22.05 \%)$ were unmarried. Majority $(51.97 \%)$ of the rural household heads had 6-10 household members with an average household size of 7 members indicating that the sampled population had a moderate household size. Further, as expected, Majority (54.72\%) of the rural household heads spent more than 12years in school, thereby suggesting that they have acquired tertiary education. The findings also revealed that Majority $(58.66 \%)$ of the rural household heads fall within the income category of less than or equal to $\mathrm{N} 300,000$.

\section{Determinants of rural household's food demand in the study area}

The determinants of household demand for some selected staple foods in the study area using QUAIDS model is presented on Table 2. The iterated, feasible, generalised non-linear leastsquares (IFGNL) estimation method, with the theoretical restrictions of adding up, homogeneity and symmetry imposed during estimation was employed in the estimation of the parameters of the QUAIDS model using Stata 14. This IFGNL method of estimation aims to address heteroscedasticity in the residuals while adhering to economic theory. The empirical analysis of the demand for some selected staples revealed that the quadratic expenditure term (Ln Expenditure $^{2}\left(\lambda^{2} s\right)$ )were found to be significant at $1 \%$ except for maize and rice thereby suggesting the preference of QUAIDs for model to AIDs model and this finding is in congruent with that of Marius, (2016).

The household's demand for rice as shown in Table 2 were positively determined by price of rice, household size, and years of education at $\mathrm{p}<0.01$. Others include price of yam, price of potato, households expenditure and years of education which were also found to be negative and significant at $\mathrm{p}<0.01$. At $\mathrm{p}<0.05$, Marital status was found to be negative while Age of household head was also found to be positive. The implication of this finding is that as the demand for rice increases, the price of rice increases while price of yam decreases. It also indicates that households that are married with large household size consume less amount of rice while respondents that are older, and possess higher income consume more of rice in the study area. The reverse is however the case for households that have acquired higher level of education as the demand for rice decrease with increase in number of years of education acquired by the households and this is attributed to the nutritional implication of consuming such food item. Households' budget share on rice increases with decrease in prices of rice in the study area.

The factors influencing the household's demand for maize were: price of maize, sex of the household head, and years of education at $\mathrm{p}<0.01$. Others include Marital status, household size Journal of the Faculty of Agriculture and Veterinary Medicine, Imo State University Owerri website: www ajol.info 
Journal of Agriculture and Food Sciences Ben-Chendo, G.N., Nwosu, F.O., Nwaiwu, I.U.O. and Igwe S.M Volume 16 Number 1, April 2018 pp. $91-106$.

and household income at $\mathrm{p}<0.01$. The household's expenditure was also found to be significant at $\mathrm{p}<0.1$. The implication of this finding is that the household's demand for maize increases with an increase in price of maize and decreases with an increase in the income of maize suggesting that maize is an inferior goods whose price varies inversely with the income of the consumer. In the same vein, the demand for maize was found to be higher in male headed households and lower among households that are married. It also indicates that householdswith large members and whose heads have acquired tertiary education consume less of maize in the study area. The household's expenditure on rice increases with an increase in price of maize in the study area.

The demand for yam were found to be positively influenced by price of potatoes and household income at $\mathrm{p}<0.01$ while the demand for cassava was found to be negatively influenced by price of cassava and household size at $10 \%$ level of significance. The demand for cassava was also found to be high among male headed household in the study area. Lastly, the demand for potatoes were positively determined by price of potatoes, households budget share on potatoes, and marital status at $\mathrm{p}<0.01$ while it was negatively influenced by sex of the household heads, and household income at $p<0.01$ and age at $p<0.05$. However, the implication of this finding is that the demand for potatoes would increase with an increase the price of potatoes and households budget share on potatoes. Similarly, it was also found that households who possess larger amount of income spent lower proportion of their income on potatoes while household with higher proportion of aged adults consume less amount of potatoes due to health reasons. Again, demand for potatoes was also found to be low among male headed households and higher among households that are married.

\section{Estimation of demand elasticity for the selected staple food items}

The empirical estimates of the Expenditure elasticity, Marshallian and Hicksian own and cross price elasticity for the study area using QUAID model is presented in Table 3. As evident from the table, the result shows that that all the expenditure elasticity for the selected staple food items were positive ranging from $0.85-1.15$ and it is consistent with a priori expectation. The implication of this is that all the selected staple food items are normal goods (Obayelu, 2009 and Ashagidigbi et al 2012). In terms of magnitude, all the staple food items except rice and yam have expenditure elasticity less than one and are therefore, regarded as necessities. That is, as income increases, the proportion of household income spent on these food item decreases. However, rice and yam are luxury goods having elasticity value greater than 1 . Furthermore, the result also revealed that the Marshallian/uncompensated and Hicksian/compensated own price elasticity as shown in the diagonal matrix are all negative as required by Economic theory. This implies that the demand for any of the staple food item will decrease if the price for that staple food increases. However, the Marshallian own price elasticity for the selected staple food item revealed that all are inelastic (with absolute values less than unity), with the exception of yam and cassava with own price elasticity value of -1.01 and -1.05 respectively. The implication of Journal of the Faculty of Agriculture and Veterinary Medicine, Imo State University Owerri website: www ajol.info 
Journal of Agriculture and Food Sciences Ben-Chendo, G.N., Nwosu, F.O., Nwaiwu, I.U.O. and Igwe S.M Volume 16 Number 1, April 2018 pp. $91-106$.

this is that, a percentage increase in the prices of all the selected staple food items will lead to a less than one percent decrease in their demand, with the exception of yam and cassava. The Hicksian/compensated own price elasticity also followed similar trend with rice, maize and potatoes been negative and inelastic while yam and cassava were however, found to be elastic with values of -1.02 and -1.13 respectively. In addition, the Marshallian cross price elasticity as shown in the off diagonal matrix revealed that almost all the selected staple food items have positive cross-price elasticity values indicating that they are substitutes except for rice with yam; rice with potatoes; maize with potatoes and vice versa which have negative cross-price elasticity values suggesting that they are complementary food items. On the contrary, the Hicksian/compensated cross price elasticity as evident in the off diagonal matrix also revealed that majority of the selected staple food items have negative cross-price elasticity values indicating that they are complements except for rice with cassava; maize with yam; yam with potatoes; potatoes with cassava, and vice versa which have positive cross-price elasticity values indicating that they are net substitutes.

\section{CONCLUSION}

The detailed study and analysis of the food demand system is crucial in designing the food and agricultural policies programmes aimed at addressing the food security and nutritional problems in the country. However, this study stems to estimate the rural households food demand for some selected staple food items in view of obtaining the key determinant of the selected staple food items as well as the price and income elasticity which provides an indication of the sensitivity of the households to market shocks. Based on the empirical findings of the study, we found that the key determinants of the rural household demands for some selected staples food items were price, total food expenditure, sex, age, marital status, years of education, household size and household head income. The findings also revealed that all the staple food items except rice and yam have expenditure elasticity less than one and are therefore, regarded as necessities. That is, as income increases, the proportion of household income spent on these food item decreases. However, rice and yam are luxury goods having elasticity value greater than unity. It was also observed from the findings that the uncompensated and compensated own price elasticity were are all negative as required by Economic theory thereby suggesting that the demand for any of the staple food item will decrease if the price for that staple food increases. Lastly, the study revealed that almost all the selected staple food items have positive cross-price elasticity values indicating that they are net substitutes for the Marshallian/uncompensated cross-price elasticity estimates while the Hicksian/compensated cross price elasticity estimates revealed that majority of the selected staple food items have negative cross-price elasticity values indicating that they are complements.

Journal of the Faculty of Agriculture and Veterinary Medicine, Imo State University Owerri website: www ajol.info 
Journal of Agriculture and Food Sciences Ben-Chendo, G.N., Nwosu, F.O., Nwaiwu, I.U.O. and Igwe S.M Volume 16 Number 1, April 2018 pp.91-106.

\section{REFERENCES}

Adepoju, O.A and Adejare, A.K. (2013). Food insecurity status of rural households during the post- planting season in Nigeria. J. Agric. Sustain. 4(1):16-35

Adetunji, M.O., and Rauf, .O. (2012).Analysis of household demand for meat, Southwest, Nigeria. Global Journal of Science Frontier Research Agriculture and Biology. 12(1). 110

Akerele, D., Tiffin, R. and Srinivasan, C. S. (2013). Household Food Demand in Nigeria: an Application of Multivariate Double-hurdle Model. A Paper prepared for presentation at the 87th Annual Conference of the Agricultural Economics Society, University of Warwick, United Kingdom.

Akinleye, S. O. (2009). Food Demand in Northern Nigeria: Implications for Food Policy. Journal of Social Science, 18(3), 209-215

Alston, J.M., Kenneth, A.F., and Green, R.D. (1994). 'Estimating Elasticity with the Linear Approximate Almost Ideal Demand System', Economic Letters 71: 351-56.

Asagunla, T. M., and Oyeyemi, A.M. (2018). Analysis of Household Expenditure in Rural Areas of Ondo State, Nigeria: Using Quadratic Almost Ideal Demand System, Journal of Economics and Sustainable Development, Vol.9, No.10. pp. 124-130.

Ashagidigbi, W. M., Yusuf, S. A. and Okoruwa, V. O. (2012). Determinants of households' food demand in Nigeria, World Rural Observations 4(4): 17-28.

Asogwa, B.C., and Umeh, J.C. (2012). Food insecurity determinants among rural farm households in Nigeria. Proceedings of International Conference on Ecology, Agriculture and Chemical Engineering (ICEACS 2012), Phuket (Thailand), December 18th $-19^{\text {th }}$.

Banks, J., Blundell, R., and Lewbel, A. (1996)."Tax Reform and Welfare Measurement: Do we Need Demand System Estimation?" Economic Journal, 106, pp. 1227-1185.

Banks, J., Blundell, R., and Lewbel, A. (1997). Quadratic Engel Curves and Consumer Demand. Rev. Econ. Stat. 79(4): 527-539.

Banks, J., Blundell, R., and Lewbel, A. (1997)."Quadratic Engel Curves and Consumer Demand", Review of Economics and Statistics, 79, pp. 527-539.

Chern, W. S., Ishibashi, K., Taniguchi, K., and Tokoyama, Y. (2002). Analysis of Food Consumption Behaviour by Japanese Households.

FMARD.(2013).Nigeria's Agricultural Transformation Agenda Mid-Term Review. Retrieved from:http://www.slideshare.net/ Transform.NG/federal-ministry-of-agriculture.

Gegios,A.,Amthor,R.,MaziyaDixon,B.,Egesi,C.,Mallowa,S.,Nungo,R.,Gichuki,S.,Mbanaso,A.an dManary,M.J.(2010). Children consuming cassava as a staple food are at risk for inadequate zinc, iron, and vitaminAintake,Plant Foods for Human Nutrition 65(1):64-70.

Huang, K., and Lin, B. (2000). Estimation of Food Demand and Nutrient Elasticity from Household Survey Data, United States Department of Agriculture, Economic Research Service, Technical Bulletin No. 1887.

Journal of the Faculty of Agriculture and Veterinary Medicine, Imo State University Owerri website: www ajol.info 
Journal of Agriculture and Food Sciences $\quad$ Ben-Chendo, G.N., Nwosu, F.O., Nwaiwu, I.U.O. and Igwe S.M Volume 16 Number 1, April 2018 pp. 91 - 106.

Huq, A.S. M.A., and Arshad, F. M. (2010). Supply Response of Potato Production in Bangladesh: A Vector Error Correction Approach. Journal of Applied Science, 10(11): 895-902.

Jones, A. D., Ngure, F. M., Pelto, G. and Young, S. L. (2013). What Are We Assessing When We Measure Food Security? A Compendium and Review of Current Metrics. Advances in Nutrition, Volume 4, pp. 481-505.

Karangiannis, G., Katranidis, S., Velentas, K. (2000). An error correction almost ideal demand system for meat in Greece. Agricultural Economics, 22(1), 29-35.

Lind, K.M., and Frandsen, S. E. (2000). Estimating Food Demand Behaviour-The Case of India. Danish Institute of Agricultural and Fisheries Economics, Agricultural Policy Research Division.

Marius, L.V. O. (2016). A Nutritional Goods and a Complete Consumer Demand System Estimation for South Africa using Actual Price data. SAJEMS NS 19. No 4:615-629

Mittal, S. (2006), Structural Shift in Demand for Food: Projections for 2020, Indian Council for Research on International Economic Relations, Working Paper No. 184.

Musa, U., Hati, S.S, and Mustapha, A. (2012). Levels of fe and $\mathrm{zn}$ in staple cereals: Micronutrient Deficiency implications in rural northeast Nigeria, Food and Public Health 2(2):28-33.

NBS. (2012).Consumption pattern in Nigeria 2009/10: Preliminary report, (Available at http://www.nigerianstat.gov.ng/).

NBS. (2016).Gross Domestic Product Report. Retrieved from :www.nigerianstat.gov.ng. $8 / 11 / 2016$.

New Delhi.

NPC. (2006). Post Enumeration Survey. National Population Commission, Abuja, Nigeria.

Nzuma, M. J., and Sarker, R. (2010). An error corrected almost ideal demand system for major cereals in Kenya. Agricultural Economics, 41:43-50

Obayelu, A.E., Okoruwa. V.O., and Ajani, O.I.Y. (2009). Cross-Sectional Analysis of Food Demand in the North Central, Nigeria. The Quadratic Almost Ideal Demand System. (QUAIDS) Approach China Agricultural Economic Review, 173 -193.

Ogunniyi, G. (2011). "An Examination of the Keynesian consumption function in Nigeria, 19751994”, Rivers journal of the Social Sciences, 1, 2(11), 34-42.

Ogunniyi, L.T., Ajao, A.O., and Oladejo, J.A. (2012).Food consumption patterns in Ogbomoso metropolis of Oyo State, Nigeria, Journal of Agriculture and Social Research 12(1):7483.

Olorunfemi, S. (2013).Demand for food in Ondo state, Nigeria: Using Quadratic Almost ideal System. Journal of Sustainable Development in Africa 15(6), 8-12, Clarion University of Pennsylvania, Clarion,Pennsylvania.

Olowa O.W., and Olowa, O.A. (2016). Food demand forecast for Nigeria (2016-2028), ScientiaAgriculturae, volume 15 (1), p 340-343.

Journal of the Faculty of Agriculture and Veterinary Medicine, Imo State University Owerri website: www ajol.info 
Journal of Agriculture and Food Sciences $\quad$ Ben-Chendo, G.N., Nwosu, F.O., Nwaiwu, I.U.O. and Igwe S.M Volume 16 Number 1, April 2018 pp. $91-106$.

Oni, O.A and Fashogboni, A.E. (2013). Heterogeneity in Rural Household Food Demand and Its Determinants in Ondo State, Nigeria: An Application of Quadratic Almost Ideal Demand System, Journal of Agricultural Science; Vol. 5, No. 2. pp. 169-177.

Pieters, H., Guariso, A. and Vandeplas, A. (2013). Conceptual framework for the analysis of the Determinants of food and nutrition security. Food secure, Volume Working paper no.13, pp. 1-51.

Poi, B. (2002). Dairy Policy and Consumer Welfare. In Three Essays in Applied Econometrics, Chapter II, Doctoral Thesis. Department of Econometrics, University of Michigan.

Poi, B. (2012). Easy demand-system estimation with Quaid's. The Stata J.12 (3): 433-446

Pomboza, R., and Mbaga, M. (2007). The Estimation of Food Demand Elasticity in Canada. Research and Analysis Directorate, Strategic Research, Agriculture and Agri-Food Canada.

Quang, C.L. (2008). An Empirical Study for Food Consumption in Vietnam, Asian Economic bulletin, vol. 25, No.3, pp. 283-292

Rizov, M., Cupak, A. and Pokrivcak, J. (2015). Food Security and Household consumption patterns in Slovakia. Italy, International Conference of Agricultural Economists.

Sanusi, R.A., Badejo, C.A., and Yusuf, B.O. (2006). Measuring Household Food Insecurity in Selected Local Government Areas of Lagos and Ibadan, Nigeria. Pakistan Journal of Nutrition, 5: 62-67

Sheng, T. Y., Shamsudin, M. N., Mohamed, Z., Abdullah, A. M., Radam, A. (2008). Complete Demand System of Food in Malaysia. Agricultural Eonomics-ZemedelskaEkonomika, 54 (10): 467-475.

Thanga, L.T. J. (2010). Consumer Behaviour in North-East India, Anshah Publishing House, New Delhi.

Thanga, L.T.J. (2013). Food Price Elasticity from Household Survey Data in India: An Application of Single Equation and System Demand Models, JEIEFB, Vol. 2 No.2 pp. 655-667

Widarjono, A. and Rucbha, S.M. (2016). Household Food Demand in Indonesia: A Two-Stage Budgeting Approach, Journal of Indonesian Economy and Business Vol. 31, No. 2,pp. $163-177$. 
Journal of Agriculture and Food Sciences Ben-Chendo, G.N., Nwosu, F.O., Nwaiwu, I.U.O. and Igwe S.M Volume 16 Number 1, April 2018 pp.91-106.

Table 1 Socio- Economic Characteristics of the respondents

\begin{tabular}{|c|c|c|}
\hline Characteristics & Frequency & Percentage \\
\hline \multicolumn{3}{|l|}{ Sex } \\
\hline Male & 153 & 60.24 \\
\hline Female & 101 & 39.76 \\
\hline Total & 254 & 100.00 \\
\hline \multicolumn{3}{|l|}{ Age } \\
\hline$\leq 40$ & 77 & 30.31 \\
\hline $41-60$ & 133 & 52.36 \\
\hline$>60$ & 44 & 17.33 \\
\hline Total & 254 & 100 \\
\hline Mean & $49.7 \pm 13.30$ & \\
\hline \multicolumn{3}{|l|}{ Marital Status } \\
\hline Unmarried & 56 & 22.05 \\
\hline Married & 198 & 77.95 \\
\hline Total & 254 & 100 \\
\hline \multicolumn{3}{|l|}{ Education } \\
\hline 5 & 29 & 11.42 \\
\hline $7-12$ & 86 & 33.85 \\
\hline$>12$ & 139 & 54.73 \\
\hline Total & 254 & 100 \\
\hline Mean & $13.09 \pm 3.96$ & \\
\hline \multicolumn{3}{|l|}{ Household Size } \\
\hline 5 & 107 & 42.12 \\
\hline $6-10$ & 132 & 51.97 \\
\hline$>10$ & 15 & 5.91 \\
\hline Total & 254 & 100 \\
\hline Mean & $7.0 \pm 3.02$ & \\
\hline \multicolumn{3}{|c|}{ Household Head Income } \\
\hline$\$ 300000$ & 149 & 58.66 \\
\hline $301000-600000$ & 80 & 31.50 \\
\hline$>600000$ & 25 & 9.84 \\
\hline Total & 254 & 100 \\
\hline
\end{tabular}

Source: Field survey data, 2018

Journal of the Faculty of Agriculture and Veterinary Medicine, Imo State University Owerri website: www ajol.info 
Journal of Agriculture and Food Sciences $\quad$ Ben-Chendo, G.N., Nwosu, F.O., Nwaiwu, I.U.O. and Igwe S.M Volume 16 Number 1, April 2018 pp. 91 - 106.

Table 2: Determinants of rural household demand for selected staple foods

\begin{tabular}{|c|c|c|c|c|c|}
\hline & Rice & Maize & Yam & Cassava & Potatoes \\
\hline Constant & $\begin{array}{c}-1.6082 * * * \\
(0.3461)\end{array}$ & $\begin{array}{l}0.2551 * * \\
(0.1285)\end{array}$ & $\begin{array}{l}0.0445^{* * *} \\
(0.0102)\end{array}$ & $\begin{array}{l}0.0206 \\
(0.0573)\end{array}$ & $\begin{array}{l}2.2880 * * * \\
(0.3036)\end{array}$ \\
\hline \multicolumn{6}{|c|}{ Price and Expenditure Coefficient } \\
\hline Ln Price of rice & $\begin{array}{l}1.6575^{* * *} \\
(0.2454)\end{array}$ & & & & \\
\hline $\begin{array}{l}\text { Ln Price of } \\
\text { maize }\end{array}$ & $\begin{array}{l}-0.0265 \\
(0.1002)\end{array}$ & $\begin{array}{l}0.1666^{* * *} \\
(0.0249)\end{array}$ & & & \\
\hline Ln Price of yam & $\begin{array}{c}-0.0273 * * * \\
(0.0072)\end{array}$ & $\begin{array}{l}0.0008 \\
(0.0017)\end{array}$ & $\begin{array}{l}0.0001 \\
(0.0005)\end{array}$ & & \\
\hline $\begin{array}{l}\text { Ln Price of } \\
\text { cassava }\end{array}$ & $\begin{array}{l}0.0495 \\
(0.0466)\end{array}$ & $\begin{array}{l}-0.0048 \\
(0.0085)\end{array}$ & $\begin{array}{l}-0.0006 \\
(0.0009)\end{array}$ & $\begin{array}{l}-0.0106 * \\
(0.0059)\end{array}$ & \\
\hline $\begin{array}{l}\text { Ln Price of } \\
\text { potatoes }\end{array}$ & $\begin{array}{c}-1.6532 * * * \\
(0.2360)\end{array}$ & $\begin{array}{l}-0.1361 \\
(0.11505)\end{array}$ & $\begin{array}{l}0.0269 * * * \\
(0.0075)\end{array}$ & $\begin{array}{l}-0.0335 \\
(0.0511)\end{array}$ & $\begin{array}{l}1.7960 * * * \\
(0.2784)\end{array}$ \\
\hline Ln Expenditure & $\begin{array}{c}-0.7313 * * * \\
(0.0510)\end{array}$ & $\begin{array}{l}0.0897 * \\
(0.0512)\end{array}$ & $\begin{array}{l}-0.0001 \\
(0.0034)\end{array}$ & $\begin{array}{l}-0.0310 \\
(0.0224)\end{array}$ & $\begin{array}{l}0.6727 * * * \\
(0.0639)\end{array}$ \\
\hline $\begin{array}{l}\text { Ln Expenditure } \\
\text { Squared }\end{array}$ & $\begin{array}{c}-0.0444 * * * \\
(0.0078)\end{array}$ & $\begin{array}{l}0.0015 \\
(0.0029)\end{array}$ & $\begin{array}{l}0.0006^{* * * *} \\
(0.0002)\end{array}$ & $\begin{array}{l}-0.0009 \\
(0.0014)\end{array}$ & $\begin{array}{l}0.0432 * * * \\
(0.0092)\end{array}$ \\
\hline & Demograp & ic Characteris & & & \\
\hline Sex & $\begin{array}{l}-0.00190 \\
(0.00223)\end{array}$ & $\begin{array}{l}0.00560 * * * \\
(0.00186)\end{array}$ & $\begin{array}{l}0.00010 \\
(0.00013)\end{array}$ & $\begin{array}{l}0.00410 * * \\
* \\
(0.00871)\end{array}$ & $\begin{array}{l}-0.00793 * * * \\
(0.00241)\end{array}$ \\
\hline Age & $\begin{array}{l}0.00016 * * \\
(0.00070)\end{array}$ & $\begin{array}{l}0.00002 \\
(0.00005)\end{array}$ & $\begin{array}{l}-3.4 \times 10^{-6} \\
\left(2.5 \times 10^{-6}\right)\end{array}$ & $\begin{array}{l}0.00003 \\
(0.00002)\end{array}$ & $\begin{array}{l}-0.00021 * * \\
(0.00007)\end{array}$ \\
\hline Marital Status & $\begin{array}{l}-0.00630 * * \\
(0.00294)\end{array}$ & $\begin{array}{l}-0.00830 * * * \\
(0.00219)\end{array}$ & $\begin{array}{l}0.00011 \\
(0.00009)\end{array}$ & $\begin{array}{l}0.00026 \\
(0.00075)\end{array}$ & $\begin{array}{l}0.01423^{* * *} \\
(0.00308)\end{array}$ \\
\hline
\end{tabular}

Journal of the Faculty of Agriculture and Veterinary Medicine, Imo State University Owerri website: www ajol.info 
Journal of Agriculture and Food Sciences $\quad$ Ben-Chendo, G.N., Nwosu, F.O., Nwaiwu, I.U.O. and Igwe S.M Volume 16 Number 1, April 2018 pp. $91-106$.

\begin{tabular}{llllll}
\hline $\begin{array}{l}\text { Years of } \\
\text { education }\end{array}$ & $-0.00188^{* * *}$ & $0.00126 * * *$ & $8.37 \times 10^{-6}$ & 0.00018 & 0.00043 \\
Household Size & $(0.00045)$ & $(0.00031)$ & $(0.00001)$ & $(0.00012)$ & $(0.00035)$ \\
& $0.00211^{* * *}$ & $-0.00211^{* * *}$ & $6.4 \times 10^{-6}$ & $-0.00034 *$ & 0.00033 \\
$\begin{array}{l}\text { Household head } \\
\text { income }\end{array}$ & $0.01072 * * *$ & $-0.00775^{* * *}$ & $0.00071 * * *$ & 0.00119 & $-0.004865 *$ \\
& $(0.00289)$ & $(0.00236)$ & $(0.00014)$ & $(0.00083)$ & $(0.00250)$
\end{tabular}

Source: Authors computation, 2018. Figures in parenthesis are standard errors

Note: $* * *=S i g n i f i c a n t @ 1 \%, * *=$ Significant @ 5\% and *= Significant @ 10\%

Table 3: Estimation of Own Price, Cross Price and Expenditure Elasticity for selected staple foods

\begin{tabular}{|c|c|c|c|c|c|}
\hline Variables & Rice & Maize & Yam & Cassava & Potatoes \\
\hline \multicolumn{6}{|c|}{ Expenditure Elasticity } \\
\hline Expenditure & 1.1506 & 0.8495 & 1.0230 & 0.9971 & 0.9197 \\
\hline \multicolumn{6}{|c|}{ Marshallian's Uncompensated Own and Cross Price Elasticity } \\
\hline Rice & -0.1138 & 0.1014 & -0.0045 & 0.1327 & -0.1158 \\
\hline Maize & 0.1775 & -0.0624 & 0.0163 & 0.0621 & -0.1934 \\
\hline Yam & -0.1667 & 0.3478 & -1.0078 & 0.0770 & 0.7496 \\
\hline Cassava & 0.5944 & 0.1647 & 0.0096 & -1.0459 & 0.2771 \\
\hline Potatoes & -0.1576 & -0.1457 & 0.0274 & 0.0815 & -0.1943 \\
\hline \multicolumn{6}{|c|}{ Hicksian's Compensated Own and Cross Price Elasticity } \\
\hline Rice & -0.5552 & -0.1610 & -0.0169 & 0.0340 & -0.4516 \\
\hline Maize & -0.1484 & -0.2561 & 0.0072 & -0.0108 & -0.4414 \\
\hline Yam & -0.5591 & 0.1145 & -1.0187 & -0.0107 & 0.4510 \\
\hline Cassava & 0.2119 & -0.0626 & -0.0011 & -1.1314 & -0.0139 \\
\hline Potatoes & -0.5104 & -0.3554 & 0.0176 & 0.0027 & -0.0741 \\
\hline
\end{tabular}

Source: Author's Computation, 2018.

Journal of the Faculty of Agriculture and Veterinary Medicine, Imo State University Owerri website: www ajol.info 